\title{
Comparison of Law Concerning the Concept of Privatization of State-Owned Enterprises in Civil Law and Common Law
}

\author{
Ayu Trisna Dewi ${ }^{1}$, Tan Kamello², Muhammad Yamin Lubis ${ }^{3}$, Edi Ikhsan ${ }^{4}$ \\ 1,2,3,4 Universitas Sumatera Utara \\ Email: Ayutrisnadewi@dharmawangsa.ac.id, tankamello@usu.ac.id,yaminlubis16@gmail.com, edi1@usu.ac.id
}

\begin{abstract}
The implementation of the nationalization of Dutch companies during the Dutch East Indies era based on Law No. 86 of 1958 concerning. The implementation of the Law on State-Owned Enterprises can be used as an important momentum for the policy of fostering BUMN by the Government, political will, commitment and consistency of policies and the determination of the governance of BUMN as a company or good corporate governance (GCG) becomes a measure. This is because Indonesia adheres to a civil law legal system as well as the Netherlands. At first the concept of privatization was a legal product and was the first program introduced by the British state with the implementation of the Anglo Saxon legal system (common law system. This basis is the main problem in comparing the concept of privatization of state-owned enterprises between 2 (two) systems. different laws in sources, definitions and mechanisms for implementing the law.This research is a descriptive type of research with a normative juridical approach. For countries that adhere to the European continental legal system (civil law) is in applying the concept of privatization, it aims to reduce state expenditure budgets, efficiency In managing state assets given to the private sector, the concept of privatization is given the greatest freedom to compete with the private sector. a work differently in different geographic contexts; commitment to competitive neutrality within the administrative framework. The conclusion of ths research are there are differences in the mechanism and concept of regulation regarding the privatization of State Owned Enterprise ( SOE ) both in civil law and common law. There are in civil law, the concept of privatization which has similarities, namely aiming to reduce the state budget, efficiency in managing state assets given to parties. private sector, whereas in a country that adheres to a common law legal system, where the concept of privatization is given the greatest freedom to compete with the private sector and there must even be transparency, there is no difference in treatment and governance between private and public companies privatized.
\end{abstract}

Keywords: Comparison, privatization, state owned enterprises

\section{INTRODUCTION}

A company founded during the Dutch East Indies era in Indonesia which turned into a State-Owned Enterprise. The implementation of the nationalization of Dutch companies during the Dutch East Indies era based on Law No. 86 of 1958 concerning Nationalization. State-Owned Enterprises, or sometimes called Government-Owned Enterprises, are business enterprises owned by governments. According to Aharoni, State-Owned Enterprises should have the following particular characteristics: owned by governments, engaged in the production of goods and services for sale, and their sales revenues should bear some relationship to cost[1].The tendency that underlies the formation of SOE in the beginning was that the government had the ability to produce its own goods and services and distribute them in the market. This condition encourages government intervention in SOE operations to become dominant. This inconsistency and ambiguity in turn has the impact of operational inflexibility, a passive and less creative work environment, more obedient to government procedures than carrying out business norms, high transaction costs and ultimately inefficiency.

Most SOEs before privatization required large subsidies and led to inflation. After the privatization faced a limited budget and credit and banking restrictions. This is important to reduce inflation and financial transaction uncertainty. The implementation of the privatization of state-owned enterprises against the provisions of Article 33 of the 1945 Constitution, is considered not to reflect and contradict the mandate of the 1945 Constitution, so that it can be described that basically, privatization is a product of the state with a common law legal system, which of course has different characteristics. and the character of law in its 
definition and application to the European continental legal system.

The implementation of the Law on State-Owned Enterprises can be used as an important momentum for the policy of fostering BUMN by the Government, political will, commitment and consistency of policies and the determination of the governance of state owned enterprises as a company or good corporate governance (GCG) becomes a measure. This is because Indonesia adheres to a civil law legal system as well as the Netherlands. At first the concept of privatization was a legal product and was a program that was first introduced by the British state with the implementation of the Anglo Saxon legal system (common law system). The problem that occurs is that there is a functional collision or functional disharmony between the profitmaking objectives of SOEs and the form of a stateowned company and social functions that must still be carried out by SOEs in accordance with the mandate of the explanation of Article 33 of the 1945 Constitution regarding the management of state land, either directly or indirectly controlled by the state. This has triggered a debate among the parties stating that the purpose and role of SOEs must be emphasized.Another thing that is also a problem is how to comparing the concept of privatization of state-owned enterprises between 2 (two) different legal systems among commmon law and eropean continental in terms of sources, definitions and mechanisms for implementing the law.

\section{LITERATURE REVIEW}

\subsection{Concept of Privatization}

Privatization is the sale of shares (companies) of a limited liability company, either partially or wholly, to other parties in order to improve the performance and value of the company, increase the benefits for the state and society,[2] and expand share ownership by the public. is a program that was first introduced by the British state with the implementation of the Anglo Saxon legal system (common law system). It is interesting whether countries that adhere to the European continental legal system ( civil law system ) also participate in the privatization program for state owned enterprises or public enterprises. Because if you look at it, there are many differences between civil law and common law, one of which is the history of the common law legal system, developed under the influence of an Adversial system in British history, as well as the source of court decisions based on custom and precedent traditions[3] .Then this legal system underlies positive law in North American countries and several Asian countries including the Commonwealth of England and Australia. continental european law that places law is law and is the authority of public legal entities that have the authority to do so.

The civil law legal system is one of the oldest legal systems in the world. While the common law legal system, was introduced for the first time from the common tradition born of habit, and is often referred to as case law. While in the Netherlands as a country that adheres to the European continental legal system. The concept of privatization is The privatization operation in the Netherlands started slowly. corporation was thought to involve a larger risk for the public sector as it reduces the government's influence on corporate policies without a concurrent reduction of its financial responsibilities. Secondly, the contracting out of public activities and the complete sale of shares in public enterprises were considered to be more efficient options, both from public management and budgetary perspectives. Between Indonesia and the Netherlands in applying the concept of privatization have the same goal of reducing the state budget, efficiency in managing state assets given to private parties. the concept of privatization is given the greatest freedom to compete with the private sector. The state has normative roles and responsibilities in various fields of life, especially in the economic field in improving the welfare of the Indonesian people, one of which is by nationalizing the Dutch East Indies-owned enterprises into state-owned enterprises.

The implementation of the nationalization of Dutch companies during the Dutch East Indies era was based on Law Number 86 of 1958 concerning Nationalization. Between 1991 and 2008, 21 stateowned companies were privatized. It was first introduced by the British Prime Minister, Margaret Teacher in 1979, when British Prime Minister Margaret Thatcher announced her plans to privatize the state company British Telecom.[2].Privatization is the process of transferring company ownership from state/public ownership to private ownership. Companies that were founded during the Dutch East Indies era in Indonesia which turned into State-Owned Enterprises, there is a tendency that they are not managed properly and optimally for the welfare of the greatest number of Indonesian people, but tend to be for the benefit of certain elite parties, so that they are not able to provide maximum contribution in accordance with their spirit. Article 33 of the 1945 Constitution which "protects the entire nation and promotes general welfare with social justice.

\subsection{Privatization Arrangements in State- Owned Enterprises}

In Indonesia, the implementation of the SOE privatization policy emerged in 2003 when Law Number 19 of 2003 was enacted. There are 2 (two) main objectives of the Government establishing a StateOwned Enterprise, namely economic goals and social goals. Indonesia is one of the countries that adheres to the European continental legal system. (civil law), because if you look at the history of Indonesia as a Dutch colony, Indonesia adopted a lot of Dutch legal rules, which basically also adheres to the Continental European legal system (Civil Law). The implementation of the privatization of state-owned enterprises against 
the provisions of Article 33 of the 1945 Constitution, is considered not to reflect and contrary to the mandate of the 1945 Constitution because the production branch which is important for the state and controls the livelihood of the people is controlled by the state, but when it is privatized, the business branch is will be controlled by private parties, both national and foreign private.[4]

The implementation of the Law on State-Owned Enterprises can be used as an important momentum for the policy of fostering SOEs by the Government, political will, commitment and consistency of policies and the determination of the governance of BUMN as a company or good corporate governance (GCG) becomes a measure.State-Owned Enterprises (hereinafter referred to as BUMN) are one of the important actors in economic activities in the national economy, which together with other economic actors, namely the private sector (big-small, domestic-foreign) and cooperatives. State owned enterprises as defined by Law Number 19 of 2003 is a business entity whose capital is wholly or most of the capital owned by the state through direct investment originating from separated state assets. State owned enterprise is to make a positive contribution to the Indonesian economy. In the people's economic system, state owned enterprises is the embodiment of the form of economic democracy that we will continue to develop gradually and sustainably. There are 2 legal products that regulate State-Owned Enterprises, namely Law Number 19 of 2003 concerning State-Owned Enterprises from separated state assets". However, in Article 9 of Law No. 19 of 2003 concerning state owned enterprises ( SOE ). There is a difference between ownership share by SOE in the form of pesero and perum where in pesero there areof a limited liability company whose capital is divided into shares, which is wholly or at least $51 \%$ (fifty) one percent) of its shares are owned by the Unitary State of the Republic of Indonesia whose main objective is to pursue profit. ." While Perum is defined as state owned enterprises whose capital is not divided into shares wholly owned by the state, which aims for the public interest in the form of providing high-quality goods and/or services that do not pursue profits based on the principles of corporate management as regulated in law. Law No. 40 of 2007 concerning Limited Liability Companies.

The arrangement for managing state assets in the form of state land by State-Owned Enterprises before independence was still subject to the legal rules of the Dutch East Indies era, and after Indonesia's independence, it still adopted Dutch legal rules, although it already had its own regulations in the form of Law 19 of 2003 concerning BUMN. There is still the influence of Dutch law contained in the product of the national law. Where as a legal entity, SOEs have a stronger dominance than business entities that are legal entities. This is because Indonesia adheres to the civil law legal system as well as the Netherlands.For countries in the Asian and African regions, privatization is seen as an effective solution to reduce state losses, even as a strategic program to increase income through the privatization of state-owned enterprises, both directly and indirectly by the state.

The problem that occurs is that there is a functional collision or functional disharmony between the profit-making objectives of SOEs and the form of state-owned enterprises and social functions that must still be carried out by SOEs according to the mandate of the explanation of Article 33 of the 1945 Constitution regarding the management of state land, either directly or indirectly controlled by the state. . This has triggered a debate among the parties stating that the purpose and role of SOEs must be emphasized. The implementation of privatization on SOEs has a positive impact on better company performance because with the new environment that is more competitive in the market and gets great demands from shareholders as measured in profitability, output, and operating efficiency, because with privatization, Government subsidies can be minimized.

\section{RESEARCH METHODS}

This research is a descriptive research with a normative juridical approach and uses qualitative data analysis because this research goals is to describe about comparison the privatization concept in civil system and common law system and by outlining the legal comparison of the concept of privatization of StateOwned Enterprises in civil and common law by using more secondary data, either in the form of references from regulations per related Law on Trade, books or journals, both national and international scientific.

\section{DISCUSSION RESULT}

\subsection{Legal Concepts in Civil Law and Common Law}

Comparative law is a process to compare laws or what is called comparative law which was first carried out since ancient times, at a time when other laws outside of ancient Greek law were adopted as sources of law either in whole or in part.[5] When viewed from its history, the civil law legal system was born as an autonomous law that developed in Continental European countries, where with colonial influence and legal codification, civil law is one of the oldest legal systems in the world and was a challenge for the development of the civil law legal system in the 19th century. .[5] Where rationalism and the critical legal system began to develop, so that the possibility of civil law was also renewed.

Although common law is not the oldest legal system in the world, but the common law legal system can also be compared with civil law [5], judging from its history, it was introduced for the first time from the common tradition that was born out of habit, and is often referred to as case law or common law. case law, which gives 
freedom to judges in court to make decisions in terms of different cases, this is different from civil law, where judges are considered as servants or servants of what has been regulated in the law. This is because civil law adheres to legal flow of legism[6]. Another weakness of civil law, according to some experts, is based on the legislative process that intersects with the process of wrestling various political, economic, socio-cultural interests and so on. The enforcement of the law with the civil law system is seen as a medium for legal certainty against the interests of capitalism and liberal politics by including interests in legislation to achieve the goals of capital and power.[4]

Comparison of law between civil and common law can also be seen from the history of receiving British colonies through trade missions, and the beginning of the common law legal system being introduced at the early stages of court centralization, especially in the era of Henry II.[5]. Some examples of common law jurisdictions are countries that are members of the British Commonwealth (commenwealth), namely India, Australia and Malaysia, etc.

\subsection{Privatization Arrangements in Civil Law and Common Law}

The regulation of the privatization of state-owned enterprises in each country that adheres to the civil law legal system with countries that adhere to common law, has differences both in concept and in the mechanism in which it was implemented.Since the late 1970 s, policies of privatization, deregulation, and competition have become increasingly important elements in the policy mix of industrialized countries. Motivated by the problems of stagflation, deteriorating public finances and the high and precisely high unemployment rates of the 1980s, the government is increasingly recognizing that "open and efficient markets for goods and services, exposed to domestic and international competition, provide the essential foundations for the economy." dynamic and high income.

In Australia itself, as an example of privatization arrangements in the common law legal system, it is explained that the factors behind Australia's apparent success include: a reform program that applied both to SOEs and to specific industries; the flexibility to apply the framework differently in different geographic contexts; anchoring the commitment to competitive neutrality in strong administrative processes; regular reviews and reporting by individual jurisdictions on the progress of their reforms" clarity in communication to enhance a nationwide understanding of the goals and mechanisms to achieve those goals; transparent public benefit tests to establish the bouderies between commercial and non-commercial public activities; and transparent and politically independent review processes establish the boundaries between commercial and noncommercial public activities; and transparent and politically independent review processes[7]. In the Netherlands itself, as a country that enforces a civil law legal system, the regulation of privatization of stateowned companies, it is explained that privatization in the Netherlands began slowly. First, corporatization is considered to involve greater risk for the public sector because it reduces the government's influence on corporate policies without reducing its financial responsibilities simultaneously. Second, contracting out public activities and selling full shares in public companies is considered a more efficient option, from both a public and budgetary management perspective. And in the Indonesia itself, the State is the main buyer of public companies there is no reason to maintain government involvement when the contractual relationship between the State and privatized companies may be more efficient. public such as the performance of private or private business entities in the private sector. And aiming to increase profits, higher incentives and prioritize the interests of the community as consumers, is also an additional motivation for the state to privatize state-owned enterprises.[8]

a. The government functions as a regulator in certain industries and the transfer of government share ownership in SOEs must be to the private sector to provide the same competitive opportunity (level playing field) to companies engaged in a particular industry. An industry is competitive enough that government intervention in the form of SOE is no longer needed; market mechanisms are functioning;

b. Encouraging the private sector to develop businesses in certain industries to minimize the government's role in SOE in slowly.

c. The role of the government in the investment sector in SOE is decreasing so that the government must transfer ownership of a SOE to the private sector in the form of selling shares or entering private capital so that the SOE can continue to develop and compete in a healthy manner in the future;

d. Privatization serves as a source of funds to reduce the burden of the state budget.[8]

In 1981, under the Van Agt-Wiegel cabinet (1977-1981) a first report, listing potential privatizations, was presented. This report was part of the so-called "reevaluation" operation which was at appraising the effectiveness and efficiency of public activities. The Van Agt-Den Uyl cabinet was decided to implement the second round of re-evaluations in 1982. Another report on privatization was presented which listed some 110 public activities which could potentially be privatised.[9]. So that privatization operation in the Netherlands started slowly. The implementation of the privatization of public companies in the Netherlands only brought relatively small changes both in its implementation and in terms of economic performance in the Netherlands, when it was be compared to other countries. The concept of nationalization in the public corporate sector carried out such as England and other countries that adhere to the common law system is carried out on a large scale, but for the Netherlands this is not the case, and thus the size of the public enterprise sector has always been relatively limited. Nevertheless, 
the goverrment still intervenes in the form of regulatory development and direct control of these public companies located in certain areas, which have a social interest function.

\section{CONCLUSION}

Comparison of the law on the concept of privatization of State-Owned Enterprises in the civil law legal system with the common law legal system, is for the countries of Indonesia and the Netherlands in applying the concept of privatization which has similarities, namely aiming to reduce the state budget, efficiency in managing state assets given to parties. private sector, whereas in a country that adheres to a common law legal system, for example, Australia, where the concept of privatization is given the greatest freedom to compete with the private sector and there must even be transparency, there is no difference in treatment and governance between private and public companies. privatized.

\section{REFERENCES}

[1] A. Siswanto and M. J. Hutajulu, "GOVERNMENT-OWNED ENTERPRISES (GOES) IN INDONESIA'S COMPETITION LAW AND PRACTICE," Yust. J. Huk., vol. 8, no. $1, \quad$ p. $93, \quad 2019$, doi: 10.20961/yustisia.v0ixx.21740.

[2] J. P. Saragih, "Milik Negara Politics and Economics of Privatizazion in The State Owned Enterprise," J. Ekon. dan Pembang., vol. 22, no. 1, pp. 83-105, 2013.

[3] F. G. John Gilessen, Sejarah Hukum. Bandung: Refika Aditama, 2005.

[4] Mustaghfirin, "Sistem Hukum Barat, Sistem Hukum Adat, dan Sistem Hukum Islam Menuju Sebagai Sistem Hukum Nasional; Sebuah Ide Yang Harmoni," Din. Huk., vol. 11, p. 91, 2011.

[5] peter de cruz, Perbandingan Sistem Hukum Common law, Civil Law and Socialist Law, CETAKAN V. Jakarta: Nusa Median , Diadit Media, 2016.

[6] Yahyanto\&Lukman Santoso Az, Pengantar Ilmu Hukum. Yogyakarta: Trussmedia, 2014.

[7] M. Rennie and F. Lindsay, "Competitive Neutrality and State-Owned Enterprises in Australia: REVIEW OF PRACTICES AND THEIR RELEVANCE FOR OTHER COUNTRIES," [8] J. J.Pinori, "KEBERADAAN PRIVATISASI BUMN DI INDONESIA," vol. III, no. 7, p. 2015, 2015, [Online]. Available: http://weekly.cnbnews.com/news/article.ht

[9] by R. C. G. H. and K. G. Berden, "REFORMING PUBLIC ENTERPRISES -CASE STUDIES: THE NETHERLANDS," 1998. 